\title{
Impact of fungicides and other preparations for seed treatment and different cultivation techniques on seed contamination of winter wheat (Triticum aestivum L. emend. Fiori et Paol.)
}

\author{
Igor ŠANTAVEC ${ }^{1}$, Darja KOCJAN AČKO²
}

Received August 23, 2011; accepted September 16, 2011

Delo je prispelo 23. avgusta 2011, sprejeto 16. septembra 2011

\begin{abstract}
Contamination of cereal crops and their products could be a result of inappropriate cultivation techniques as well as disregarding usual agro-technical measures like the seed treatment with fungicides. The aim of the study was to determine the impact of pre-sowing seed treatment on wheat seed infection and contamination of produced grains from the field trial at the Biotechnical faculty (BF) and contamination of crop samples from Slovene farms with conventional and organic type of production. In our laboratory we performed grain incubation on agar with various disinfectants before sowing the grain on the field. We found that seed treatment with fungicides Maxim 050 FS and Vitavax 200-FF had significantly improved the health status ( $2 \%$ infected grains) compared to untreated processed seed (25\% infected grains). The effectiveness of both tested fungicides was significantly better (2\% infected grains) compared to the Agrostemin and Fitolife preparations, which are allowed in organic farming (15\% infected grains). Compared to the untreated seed, treating the seeds with both fungicides and the Agrostemin preparation reduced visible ear contamination with fusariosis during the time of dough maturity. With incubation of grain from our field experiment with different seed treatments, the positive effect of fungicides on the health status of grain yield was confirmed ( $27 \%$ infected grains), compared to sowing of seed that was not treated with disinfectants $(34 \%$ infected grains). When compared to the control group a positive effect of wheat seed treatment with disinfectants used in organic farming was determined. Furthermore, seed treatment with fungicides had a greater influence on improving the health status of produced grain, compared to the above mentioned preparations allowed in organic farming $(29 \%$ infected grains). The effect of seed treatment on the health status of the grain was the greatest when using the Vitavax 200-FF fungicide. The percentage of infected grains in laboratory incubation of produced wheat grain on agar, sampled from
\end{abstract}

eight Slovenian farms, ranged from 1.5 to $19.5 \%$. Contamination of sampled grain from organic production $(7 \%$ infected grains) was comparable with infection of grain from the conventional farming ( $8.4 \%$ infected grains), where the infection ranged from $1.5 \%$ to $19.5 \%$.

Key words: crop management, Triticum aestivum, seed infection of winter wheat, fungicides and the other preparations for seed treatment, laboratory tests for infection of seed

\section{IZVLEČEK}

\section{VPLIV FUNGICIDOV IN DRUGIH PRIPRAVKOV ZA RAZKUŽEVANJE SEMENA TER NAČINOV PRIDELAVE NA OKUŽENOST SEMENA OZIMNE PŠENICE (Triticum aestivum L. emend. Fiori et Paol.)}

Onesnaženja pridelkov in izdelkov žit so lahko posledica slabe pridelovalne prakse, zlasti neupoštevanja običajnih agrotehničnih ukrepov, med katerimi je razkuževanje semena. Namen raziskave je bil ugotoviti vpliv razkuževanja semena na okuženost semena pšenice pred setvijo in pridelka zrnja iz poljskega poskusa Biotehniške fakultete $(\mathrm{BF})$ ter okuženost vzorcev pridelanega zrnja iz konvencionalne in ekološke pridelave. Pri laboratorijski inkubaciji zrnja na agarju pred setvijo poljskega poskusa na $\mathrm{BF}$ z različnimi razkužili smo ugotovili, da tretiranje semena s fungicidoma Maxim 050 FS in Vitavax 200-FF (2\% okuženih zrn) pomembno izboljša zdravstveno stanje $\mathrm{v}$ primerjavi $\mathrm{z}$ nerazkuženim dodelanim semenom (25\% okuženih zrn). Delovanje obeh fungicidnih pripravkov je bilo statistično značilno boljše (2\% okuženih zrn) od pripravkov Agrostemin in Fitolife, ki sta dovoljena v ekološkem kmetijstvu (15\% okuženih zrn). Razkuževanje semena $s$ fungicidoma in pripravkom Agrostemin je $v$ primerjavi z nerazkuženim semenom zmanjšalo vidne okužbe klasov s fuzariozami v času voščene zrelosti. Pri inkubaciji

\footnotetext{
Assistant, Ph. D., University of Ljubljana, Biotechnical Faculty, Department of Agronomy, Jamnikarjeva 101, SI-1111 Ljubljana, Slovenia, email: igor.santavec@bf.uni-lj.si

2 Assoc. Prof., Ph. D., University of Ljubljana, Biotechnical Faculty, Department of Agronomy, Jamnikarjeva 101, SI-1111 Ljubljana, Slovenia, e-mail: darja.kocjan@bf.uni-lj.si
} 
pridelka zrnja iz poljskega poskusa z različnimi razkužili smo potrdili pozitiven vpliv tretiranja semena $\mathrm{s}$ fungicidoma na zdravstveno stanje pridelanega zrnja (27 \% okuženih zrn) v primerjavi s setvijo nerazkuženega semena (34\% okuženih zrn). V primerjavi s kontrolo je bil ugotovljen pozitiven vpliv razkuževanja semena pšenice s pripravkoma, ki ju lahko uporabljajo tudi ekološki kmetje. Razkuževanje s fungicidoma je imelo večji vpliv na boljše zdravstveno stanje pridelanega zrnja kot pripravka dovoljena v ekološkem kmetijstvu (29 \% okuženih zrn). Vpliv razkuževanja na zdravstveno stanje pridelanega zrnja je bil največji pri fungicidu Vitavax 200-FF. Pri laboratorijski inkubaciji pridelka zrnja pšenice na agarju $\mathrm{z}$ osmih slovenskih kmetij smo ugotovili, da je bila okuženost vzorcev pridelanega zrnja iz ekološke pridelave (7 \% okuženih zrn) na ravni vzorcev iz konvencionalne pridelave $(8,4 \%$ okuženih zrn), pri katerih pa je bil razpon okuženosti od 1,5\% do $19,5 \%$.

Ključne besede: načini pridelave, Triticum aestivum, okuženost semena za setev in pridelanega zrnja ozimne pšenice, fungicidi in drugi pripravki za razkuževanje semena, laboratorijski testi okuženosti semena

\section{INTRODUCTION}

Contamination with fungal diseases is becoming more and more common, causing a food safety risk for the consumers of cereal products. Numerous fungi contaminating the wheat grains form and secrete secondary metabolites, the so called mycotoxins. These mycotoxins are the cause of mycotoxicosas - diseases than can cause direct poisonings like chronic liver illness and tumour activation. Mycotoxins are formed by the Aspergillus, Penicilium in Fusarium fungal plant pathogens that are frequently present on our cereal grains (Kovač, 2009; Jakovac-Strajn et al., 2010). Fusarium fungi can contaminate grains during the growing period and in the ripening phase. Weather conditions, especially during the time of grain ripening have an important influence on fungi development on the wheat crop, since wet conditions importantly increase the possibility of fungal development in that morphological state. (Cowger et al., 2009). Poor agricultural practice especially ignoring the usual agro technical measures can cause higher occurrence of different fungal infections on wheat grains.

Seed treatment is the basic measure to assure an adequate health of crops at emergence and during further growth of plants. Numerous diseases could be transferred to the wheat crops through the use of poorly cleaned and untreated or inappropriately treated seed. They can completely prevent the emergence of plants, reduce overwintering or systemically infected the plants that later become a new focal point for further spreading of the disease. Stinking bunt (Tilletia tritici (Bjerk.) Wolff), Dwarf bunt (Tilletia controversa Kühn), Septoria leaf blotch (Septoria tritici Roberge ex Desmaz), Septoria leaf and glume blotch (Phaeosphaeria nodorum (E. Müller) Hedjaroude) and Loose smut (Ustilago nuda (Jensen) Rostr. f. sp. tritici Schaffnit) (Maček, 1987;) can all be transferred through the seed. Also the agents causing the Pink snow mould (Monographella nivalis (Schaffnit) E. Müller) with similar signs as Fusarium fungi just without violet-pink coloration could be transferred through the seed. Different to the fusariosis the fungus causing the Pink snow mould does not secrete mycotoxins (Maček, 1987; Murray et al., 2009).

During the last few years there is an increasing trend of sowing untreated wheat seed in Slovenia; mainly from two reasons. The first reason is the prohibition to treat seed on agricultural holdings which also caused the withdrawal of treatment substances from retail shops (Rules on ..., 2009). The second reason is organic farming guidelines that prohibit the use of synthetic chemical substances for the seed disinfection. The rules for organic farming in Slovenia do not allow the use of any substances used exclusively for the seed treatment with a purpose to reduce the hazard of contamination with agents causing fungal diseases transmitted through the seed. (Bavec et al., 2009). Treatment of certified seed is legally obligatory only when disease thresholds for different diseases have been exceeded (Rules on marketing ..., 2005).

Other agro technical measures performed before sowing and during the vegetation period can also influence the health condition of the seed. Adequate crop rotation, tillage, fertilizing (mainly with nitrogen), protection with fungicides and other cultivation procedures are among the most efficient measures. In Slovene cultivation practice a relatively narrow crop rotation with a high share of maize and wheat represent an important hazard for the poor health status of wheat seed (Kocjan and Šantavec, 2010; Statistical yearbook, 2008; Tajnšek and Šantavec, 1998).

The goal of this study was to test the impact of fungicides and other seed treatment preparations to the contamination of wheat seed before sowing and contamination of grain crop from the field trials at the Biotechnical faculty (BF). With the analysis of wheat seed samples obtained from eight Slovene wheat producers we examined the contamination of produced grains depending on the wheat cultivation practice (conventional, organic). 


\section{MATERIALS AND METHODS}

\subsection{Contamination of wheat seed from the BF field trial}

In the first part of the research we studied the influence of different fungicides and other preparations on contamination of wheat seed with fungal diseases. We used the Ficko winter wheat variety, which was developed in Croatia and registered in Slovenia in 2007.

The following treatments were included in our field trial:

K - $\quad$ untreated, certified processed seed,

A - certified processed seed that we treated with Agrostemin (concentrate) in the amount of $30 \mathrm{~g} / \mathrm{ha}$,

F - $\quad$ certified processed seed, that we treated with Fitolife in the amount of $300 \mathrm{~g} / 100 \mathrm{~kg}$ of seed,

M - certified processed seed, that we treated with Maxim 050 FS fungicide (difenoconazol 2.5\% + fludioxonil $2.5 \%$ ) in the dose of $1.51 / \mathrm{t}$,

V - certified processed seed treated by the processor with the fungicide Vitavax 200-FF (carboxin 20\%+ thiram 20\%).

Treatments $\mathrm{A}$ and $\mathrm{F}$ are the two seed treatments allowed in organic farming. Both this preparations are allowed in organic farming (Bavec et al., 2009), but until now they were mostly used for the treatment of plants and not for the treatment of the seed. Agrostemin is a growth promoter acquired from the Common corncockle (Agrostemma githago L.). Fitolife is a natural mineral substance with the majority of calcium carbonate $\left(\mathrm{CaCO}_{3}\right)(88 \%)$, also including $4 \%$ of magnesium carbonate $\left(\mathrm{MgCO}_{3}\right)$ and $0.3 \%$ of iron. With the $\mathrm{M}$ treatment we tried to illustrate the most common seed treatment used on the Slovene farms.

One part of the seeds from all five treatments was used for the incubation in the laboratory to determine the presence of the pathogenic fungi. Incubation was performed in four repetitions. The wheat seed was incubated in closed petri dishes filled with sterilised agar; we have placed fifty wheat seeds into each dish. A 5-day incubation was carried out in the growth chamber at permanent light and on 20 to $22{ }^{\circ} \mathrm{C}$. After the incubation period we counted all contaminated seeds. Any seed with visible development of fungal mycelium was considered contaminated.

In the autumn of 2009 we started our field trial by sowing the wheat seed of Ficko variety on the laboratory field at the Biotechnical faculty in block trial with three repetitions.
The soil on the laboratory field is medium deep pseudogley (planosol), with the silt loam texture, and meliorated, but still occasionally flooded on the surface at times of heavy rains. It contains $4.5 \%$ of organic matter through the depth of arable land and is well supplied with phosphorus and potassium. The previous crop was the seed maize.

The sowing was performed on the October 19th with the plot sowing machine to the $12.5 \mathrm{~cm}$ row spacing, the sowing density was 700 sprouting seeds $/ \mathrm{m}^{2}$. The size of the basic parcel was $5.6 \mathrm{~m}^{2}$. The 1000 -grain weight of the seed was 44 g. The trial was fertilized with $\mathrm{KAN}(60 \mathrm{~kg} \mathrm{~N} / \mathrm{ha})$ during the tillering period (BBCH 21-23). The crop was not treated with fungicides for the purpose of monitoring the influence of the seed treatment to the incidence of fungal diseases. At the time of dough maturity (BBCH 73-75) we determined the crop density (number of ears $/ \mathrm{m}^{2}$ ); at the same time we counted the ears with visible contamination with the Fusarium fungus. We than calculated the share of contaminated ears. All counting was performed using the $50 \mathrm{~cm} \times 50 \mathrm{~cm}$ wire frame, twice on all parcels. The trial was harvested with the plot harvester on July 21st. The grain produced on individual plots was incubated in laboratory conditions in two repetitions. We used the same incubation procedure and the same procedure to determine the share of contaminated seeds as for the grains intended for sowing.

\subsection{Contamination of wheat grains in conventional and organic production}

In July 2010 we obtained the samples of wheat grain produced on eight wheat producing farms (six conventional and two organic) in different geographic areas of Slovenia. We questioned the owners of the farms about the previous crop in the rotation, cultivation methods, intensity of fertilization with mineral nitrogen and protection against fungal diseases. The seed samples from eight locations were incubated in laboratory conditions in four repetitions. The incubation procedure and the method for the determination of the share of contaminated seed were the same as the ones used in the trial with the two fungicides and other seed treatment preparations.

With analysis of variance we analysed the data from both parts of the trial using the Statgraphics Plus for Windows and presented the results in the form of graphs.

\section{RESULTS AND DISCUSSION}

\subsection{Results of wheat seed treatment}

After incubation of the certified processed wheat seed, the average $25 \%$ of all grains were contaminated with different fungal disease agents (Figure 1). Treatment with the two preparations that are allowed in organic farming (Figure 1, treatments $\mathrm{A}$ and $\mathrm{F}$ ), reduced the seed contamination by $40 \%$. Both preparations equally improved the health state of the wheat seed in the laboratory conditions. Even better effects on the health status of the wheat seed compared to the untreated wheat seed was proved for the treatment with organic fungicides (Figure 1, treatments $\mathrm{M}$ and $\mathrm{V}$ ). The share of contaminated seeds has been reduced by $90 \%$. The positive effect of the Vitavax 200FF fungicide to the general health state of wheat seed was also proved by 
Samobor et al. (2008), but they also state in their paper that treatment with fungicide Vitavax 200FF does not influence the reduction of seed contamination with the Fusarium fungi.

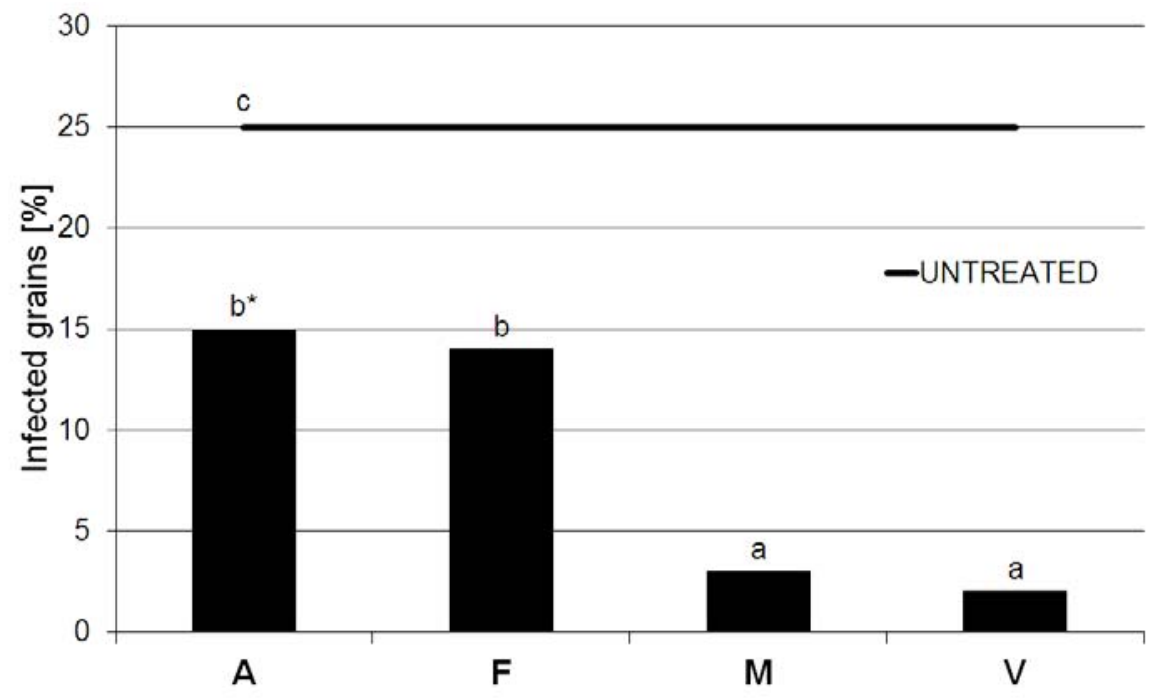

Figure 1: Impact of wheat seed treatment on development of contamination in laboratory incubation (agar, 5 days, 20 to $22{ }^{\circ} \mathrm{C}$ ). Different letters above the columns mark the statistically significant difference between the two treatments (Duncan, $\mathrm{p} \leq 0.05$ ).

At the time of dough maturity we also estimated the share of ears with visible contamination with Fusarium. All ears with visible contamination of bract at least in one spikelet were considered contaminated. As we expected a higher number of contaminated ears was detected in the control group $(\mathrm{K})$ where we only sow untreated certified wheat seed (Figure 2) and $2 \%$ of all ears were contaminated. In the $\mathrm{F}$ treatment where we treated the seed with the Fitolife preparation contamination was statistically significantly equal to the contamination in the control group. There was statically significantly less contaminated ears in $\mathrm{A}, \mathrm{M}$ and $\mathrm{V}$ treatments than in the control treatment $\mathrm{K}$ (Figure 2).

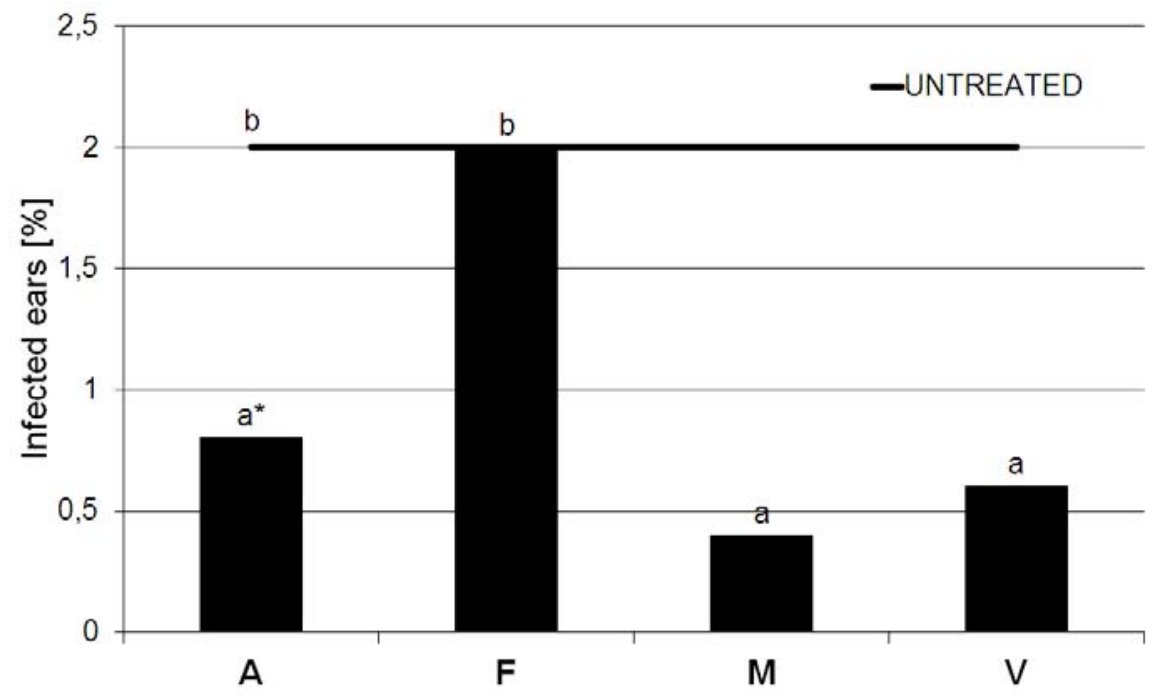

Figure 2: Impact of wheat seed treatment on the share of visibly contaminated ears with fusariosis in the dough maturity stage (Ljubljana, laboratory field BF, last decade of June, 2010). Different letters above the columns mark the statistically significant difference between the two treatments (Duncan, $\mathrm{p} \leq 0.05$ ).

After the harvest the seed grains produced in the trial were incubated in the same way as before the sowing of the trial. The share of contaminated grains was statistically significantly the highest at the control group 
$(\mathrm{K})$, where wheat grains were not treated before sowing (Figure 3). On average one third of incubated grains were contaminated. The health state of the produced grains was the best at the $\mathrm{M}$ and $\mathrm{V}$ treatments with fungicides $(27 \%$ of contaminated grains). Higher seed contamination was determined with the use of the preparations Agrostemin (A) and Fitolife (F) (29\% contaminated grains), but the average contamination of grains treated in these two ways was still lower as the control group. Samobor et al. (2010) state in their paper that the Fitolife has a lesser effect on health status of produced wheat grain compared to the Vitavax 200-FF fungicide, however they confirmed statistically significant differences in the share of contaminated grains between the two treatments only for the contamination with Alternaria alternata. They could not prove the differences between the two preparations for the contaminations with other thirteen tested fungal species. Different results were reported by Zemljič et al. (2008), the share of grain contamination with Fusarium sp. fungi was higher when sowing treated seed than for the untreated seed.

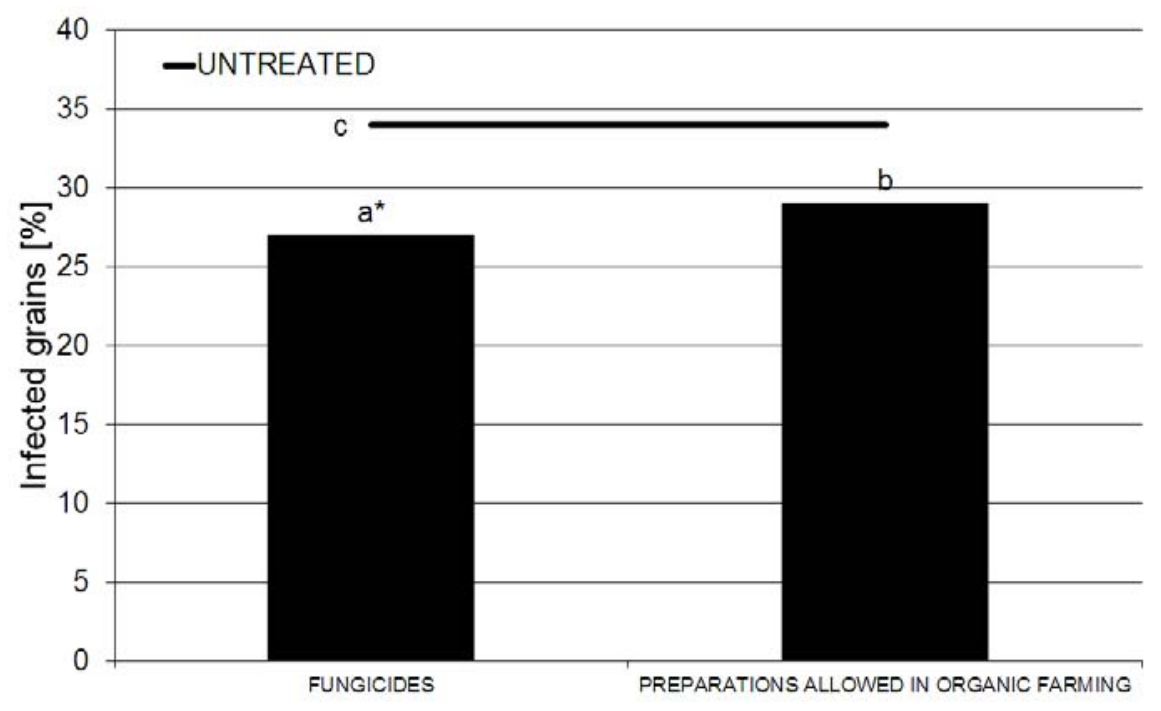

Figure 3: Contamination of wheat grain from the field trials with different seed treatments (Ljubljana, laboratory field BF, 2009-2010) after laboratory incubation (agar, 5 days, 20 to $22{ }^{\circ} \mathrm{C}$ ). Different letters above the columns mark the statistically significant difference between the treatments $(\mathrm{p} \leq 0.05)$.

We could not confirm statistically significant regression and correlation connection between the share of contaminated ears at the stage of wax maturity and the share of infected grains in the final crop. The explanation why plants with higher infection level do not give higher ratio of infected grain could partly be contributed to the fact that usually grains in contaminated ears are very light, highly damaged or shrivelled, and stay on the field after the crop is harvested by a machine harvester, which can later cause permanent contamination of the wheat crop on this soil, especially in the narrow crop rotation.

\subsection{Contamination of wheat grains from different types of production - results}

Grain samples from two organic farmers and six conventional producers were incubated in the same way as all the seed from the previously presented trial. All data on the location of the farm, type of production, insensitivity of nitrogen fertilization, crop rotation and treatments with fungicides are presented in Table 1.
Compared to the conventional production $(8.4 \%$ contaminated grains) the grain samples from organic farms ( $7 \%$ of infected grains) had in average the similar lever of contamination (Figure 4). Similar findings were confirmed in Czech Republic where the content of DON, which is a consequence of grain contamination with Fusarium, fungi, the samples from organic farming were no different from the samples from intensive conventional production (Váňová et al., 2008). The results show that samples obtained from the central part of Slovenia had the highest variability of seed contamination (from $1.5 \%$ to $19.5 \%$ contaminated grains). This also shows that humid climate increases the incidence of seed contamination. Higher number of wet weather days after the wheat flowering period increases the grain contamination with fungal infections (Cowger et al., 2009). Figure 4 shows that despite consistent protection a small share of corn and grains in the crop rotation do not necessarily bring a good health condition of the crop. Especially corn with conservation tillage as a previous crop increases the risk of a serous wheat gain contamination with Fusarium, fungi, which 
were confirmed by Swiss researchers from 284 wheat samples from 16 cantons (Vogelsang et al., 2009). Zemljič et al. (2008) believe that the higher intensity of nitrogen fertilization is not always in correlation with higher levels of seed contamination. They contribute a high influence to the selection of the varieties (Zemljič et al., 2008; Argyris et al., 2003), although great differences in contamination of different varieties can occur also between years and locations due to more or less favourable conditions for contamination (Hecker et al., 2009). Considering our own research and the results from other researchers we can conclude that the seed contamination is caused by a mix of environmental factors beyond producers influence. It's not surprising that it is possible to grow a healthy wheat crop despite narrow crop rotation with consistent use of relevant agro technical measures and in optimal weather conditions.

Table 1: Crop rotation and agro technical measures in wheat production on eight Slovene farms that gave the samples for the laboratory incubation of wheat grain in July 2010 (K - conventional farming, E - organic farming)

\begin{tabular}{|c|c|c|c|c|c|c|c|c|}
\hline \multirow{2}{*}{$\begin{array}{l}\text { Geographic } \\
\text { area } \\
\text { Farm no. }\end{array}$} & \multicolumn{2}{|c|}{$\begin{array}{l}\text { Pomurje and } \\
\text { lower } \\
\text { Podravje }\end{array}$} & \multicolumn{2}{|c|}{$\begin{array}{c}\text { Savinjska } \\
\text { valley with } \\
\text { Kozjansko }\end{array}$} & \multicolumn{3}{|c|}{$\begin{array}{c}\text { South Gorenjska } \\
\text { with Ljubljana } \\
\text { basin }\end{array}$} & \multirow{2}{*}{$\begin{array}{c}\begin{array}{c}\text { South- } \\
\text { east } \\
\text { Dolenjska }\end{array} \\
8\end{array}$} \\
\hline & 1 & 2 & 3 & 4 & 5 & 6 & 7 & \\
\hline $\begin{array}{l}\text { Cultivation } \\
\text { type }\end{array}$ & K & E & $\mathrm{K}$ & E & K & $\mathrm{K}$ & K & $\mathrm{K}$ \\
\hline Pre-crop & maize & buckwheat & maize & maize & potatoes & maize & $\begin{array}{c}\text { red } \\
\text { clover }\end{array}$ & potatoes \\
\hline $\begin{array}{l}\text { Share of grains } \\
\text { and maize in } \\
\text { last four years } \\
\text { [\%] }\end{array}$ & 100 & 50 & 25 & 50 & 25 & 25 & 25 & 50 \\
\hline $\begin{array}{l}\text { Number of } \\
\text { fungicide } \\
\text { sprayings }\end{array}$ & 2 & 0 & 1 & 0 & 1 & 1 & 2 & 1 \\
\hline $\begin{array}{l}\text { Number of } \\
\text { nitrogen } \\
\text { fertilizations }\end{array}$ & 3 & 0 & 2 & 0 & 3 & 3 & 3 & 1 \\
\hline
\end{tabular}

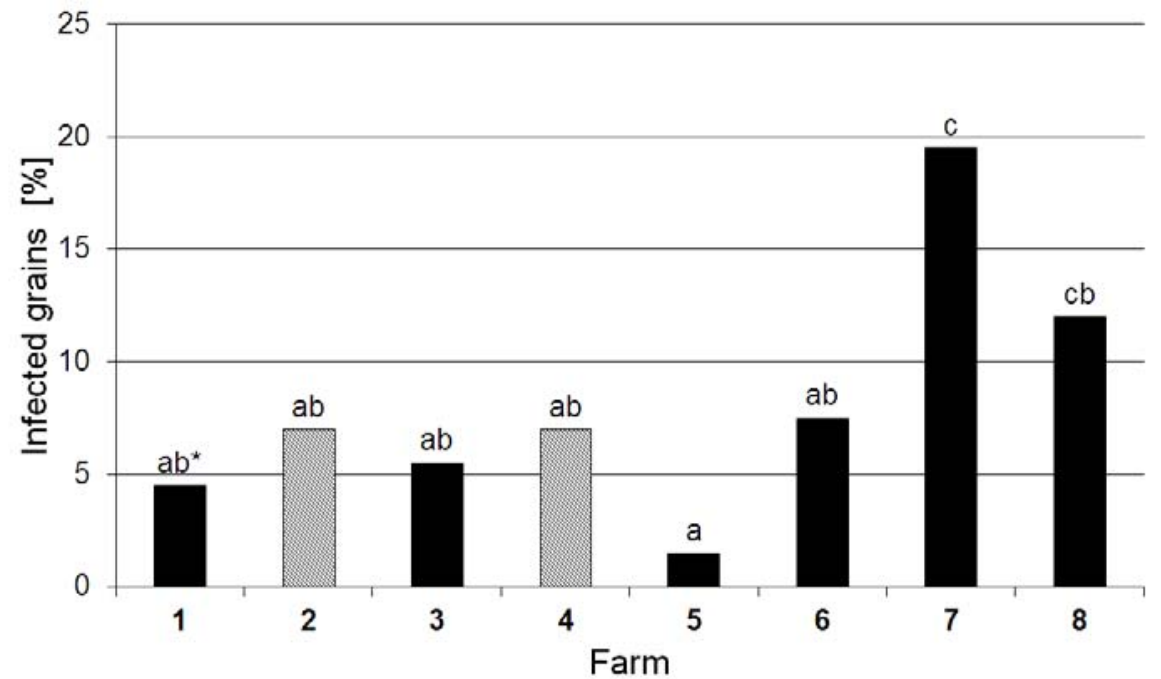

Figure 4: Seed contamination of wheat grain from eight Slovene farms at laboratory incubation (agar, 5 days, 20 to $22{ }^{\circ} \mathrm{C}$ ). Different letters above the columns mark the statistically significant difference between the two treatments (Duncan, $\mathrm{p} \leq 0,05$ ) The two lighter columns represent the samples from the organic farms. 


\section{CONCLUSIONS}

Treating the wheat seed with fungicides has importantly improved the health status of the seed between sprouting in laboratory conditions. Alternative seed treatment preparations that can be used in organic farming have also improved the health status of sprouting seeds in laboratory conditions, but their effect was not as strong as with fungicides.

Our results prove that the health state of produced grain was best when sowing the seed treated with fungicides, the two preparations allowed in organic farming were slightly less effective but still importantly reduced crop contamination with different fungal diseases within the organic farming guidelines.

We could not establish a connection between different cultivation techniques and plant-health situation. Wheat seed contamination was the same in samples from organic and conventional farms. Protection with fungicides and suitable crop rotation do not assure a healthy crop since the grain health is highly dependent on weather conditions during the ripening period which cannot be influenced by producers.

\section{REFERENCES}

Bavec, M., Robačer, M., Repič, P., Štabuc Starčevič, D. 2009. Sredstva in smernice za ekološko kmetijstvo. Maribor, Univerza $\mathrm{v}$ Mariboru Fakulteta za kmetijstvo in biosistemske vede, Inštitut za ekološko kmetijstvo: 149 str.

Cowger, C., Patton-Özkurt, J., Brown-Guedira, G., Perugini, L. 2009. Post-Anthesis Moisture Increased Fusarium Head Blight and Deoxynivalenol Levels in North Carolina Winter Wheat. Phytopathology 99, 4: 320-327

Hecker, A., Vogelsang, S., Werrstein, F., Forrer, H-R. 2009. Befall einiger Winterweizensorten durch FusariumArten. Agrarforschung 16, 7: 244-249

Jakovac-Strajn, B., Vengušt, A., Ujčič-Vrhovnik, I., PavšičVrtač, K., Tavčar-Kalcher, G. 2010. The natural occurrence of toxigenic moulds and mycotoxins in Slovenian primary grain production. Acta agriculturae Slovenica 95, 2: 121-128

Kocjan Ačko, D., Šantavec I. 2010. Crop rotation on arable and livestock farms in Slovenia. Acta agriculturae Slovenica 95, 3: 245-251

Kovač, B. 2009. Kemijska tveganja izdelkov iz žit : ostanki fitofarmacevtskih sredstev in mikotoksini. V: Zbornik predavanj in referatov 9. slovenskega posvetovanja o varstvu rastlin, Nova Gorica, 4.-5. marec 2009. Maček, J. (ur.). Ljubljana, Društvo za varstvo rastlin Slovenije: 2530

Maček, J. 1987. Posebna fitopatologija Patologija poljščin. 2. Izdaja. Ljubljana, Univerza Edvarda Kardelja v Ljubljani, Biotehniška fakulteta, VTOZD za agronomijo: 286 str.

Murray, T.D., Parry, D.W., Cattlin, N. 2009. Diseases of small grain cereal crops A colour handbook. London, Mansoon Publishing Ltd: 142 str.
Pravilnik o spremembah in dopolnitvah Pravilnika o dolžnostih uporabnikov fitofarmacevtskih sredstev. Ur.l. RS št. 30-1323/09

Pravilnik o trženju semena žit. Ur. L. RS št. 8-210/05

Samobor, V., Horvat, D., Kasteli, B., Jošt, M. 2008. Effect of stone meal on control of seed-borne diseases in wheat. Agronomski glasnik 70, 6: 563-572.

Samobor, V., Horvat, D., Jošt, M. 2010. Efikasnost predsjetvenog tretiranja sjemena pšenice u ekološkoj poljoprivredi. Sjemenarstvo 27, 3-4: 113-123.

Statistični letopis Republike Slovenije 2008. Ljubljana, Statistični urad RS: 480 p.

Tajnšek, A., Šantavec, I. 1998. Možnosti za sonaravni poljski kolobar $\mathrm{v}$ Sloveniji $\mathrm{v}$ primerjavi $\mathrm{z}$ državami EU. V: Kmetijstvo in okolje, Bled, 12.- 13. 3. 1998: 223-230.

Váňová, M., Klem, K., Míša, P., Matušinsky, P., Hajšlová, J., Lancová, K. 2008. The content of Fusarium mycotoxins, grain yield and quality of winter wheat cultivars under organic and conventional cropping systems. Plant Soil Environ. 54, 9: 395-402

Vogelsang, S., Jenny, E., Hecker, A., Bänziger, I., Forrer, HR. 2009. Fusarien und Mykotoxine bei Weizen aus Praxis-Ernteproben. Agrarforschung 16, 7: 238-243

Zemljič, A., Rutar, R., Žerjav, M., Verbič, J. 2008. Vpliv sorte, gnojenja $\mathrm{z}$ dušikom in razkuževanja semena na okuženost zrnja pšenice s Fusarium $s p$. in okuženost $\mathrm{z}$ mikotoksini. V: Novi izzivi v poljedelstvu 2008.: zbornik simpozija. Novi izzivi v poljedelstvu 2008, Rogaška Slatina, 4. in 5. dec. 2008. Tajnšek, A. (ur.). Ljubljana, Slovensko agronomsko društvo - SAD: 257-262 